\title{
Forte Avalos: tra memoria e oblio, un disegno per ricordare
}

\author{
Eleonora Di Mauro
}

\section{Abstract}

Nella Sicilia del XVI, per far fronte alle incursioni dei turchi e barbareschi, il governo viceregio spagnolo mise in atto la costruzione di alcuni forti marittimi allo scopo di difendere le coste dell'Isola. Tra questi, nel porto della città di Augusta venne costruito intorno al 1570 forte Avalos, una piccola fortificazione alla moderna caratterizzata dal particolare impianto planimetrico semicircolare, capace di avere un vasto raggio d'azione. Vari ed ampi sono stati gli studi condotti sulle vicende e sulle raffigurazioni storiche del forte anche in relazione al sistema marittimo fortificato delle coste siciliane. Tuttavia, non sempre tali studi sono stati messi in relazione allo stato effettivo del bene che, sorgendo in piena zona militare e su un isolotto, non è affatto facile da raggiungere, né tanto meno da rilevare. Con l'ausilio di moderni e sofisticati strumenti, in casi simili, molte difficoltà possono essere superate. Nel caso specifico è stato effettuato il rilievo mediante la stazione totale, dal quale è emerso uno stato di forte degrado con gravi dissesti strutturali. I ritardi nelle operazioni di consolidamento e restauro del bene rischiano di condurlo alla distruzione, attraverso questo lavoro si propone quindi di lasciare quantomeno una traccia di un bene architettonico che matericamente sta scomparendo, avvalendosi della connessione tra varie tecniche e risorse in vista della costruzione di una memoria che abbia una consistenza visiva, metrica e storica.

Parole chiave

documentazione, fortificazioni, forte Avalos, rappresentazione, virtualità

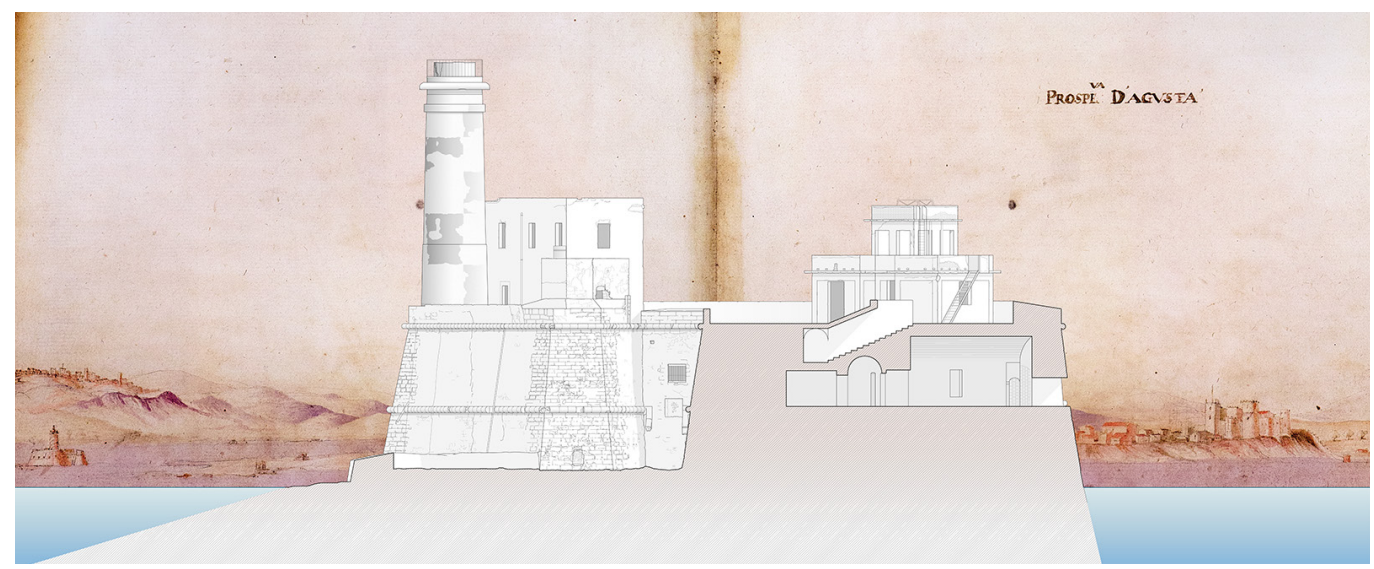




\section{Introduzione}

Il vasto patrimonio architettonico italiano se da un lato rende unico il nostro Paese, dall'altro genera la richiesta continua di risorse da destinare alla manutenzione, e in casi di grave dissesto, al restauro e a interventi mirati alla sua conservazione; tali operazioni, intese nel senso materiale del termine non sono sempre possibili per svariati motivi.

Vi sono casi in cui è l'ambiente stesso, in cui sorge un determinato bene architettonico, a dettare vincoli stringenti per la sua manutenzione, altri in cui i conflitti tra i vari enti, che si contendono o scaricano la responsabilità della gestione, rendono estenuanti i tentativi di conservazione, abbandonandoli così alla rovina, facendoli cadere nell'oblio.

Già verso la metà dell'800, grazie anche all'avvento della fotografia, nasceva l'esigenza di creare una memoria del patrimonio architettonico. L'opera dei fratelli Alinari, che nel tempo hanno costruito una collezione fotografica che conta tantissimi esemplari [Cardaci,Versaci 20 I3] ne è un esempio chiarissimo. Ciò fu dettato dalla sempre più forte consapevolezza che in caso di calamità o del naturale degradarsi del bene architettonico, in mancanza di un database, non si sarebbe persa solo la materia ma anche la memoria del bene.

Nella costa sudorientale della Sicilia, come in molte altre parti del Sud Italia, non mancano esempi di beni architettonici che versano in uno stato di grave degrado. Alcuni di essi sono addirittura inglobati nelle zone industriali, per cui anche lo stesso raggiungerli e quindi censirli diventa quasi impossibile.

In questa casistica si può far rientrare una piccola fortificazione marittima situata nella rada di Augusta, in piena zona militare, forte Avalos (fig. I) che assieme ai forti Garcia e Vittoria costituivano un primo tentativo di adeguamento delle difese agli standard del $\mathrm{XVI}$ secolo [I].

\section{Vicende storiche}

La Sicilia, per la sua collocazione geografica al centro del Mediterraneo, ha da sempre rappresentato un polo di scambi e connessioni commerciali, culturali e via preferenziale di accesso all'Europa. Ciò l'ha resa oggetto delle mire espansionistiche degli imperi e dei popoli

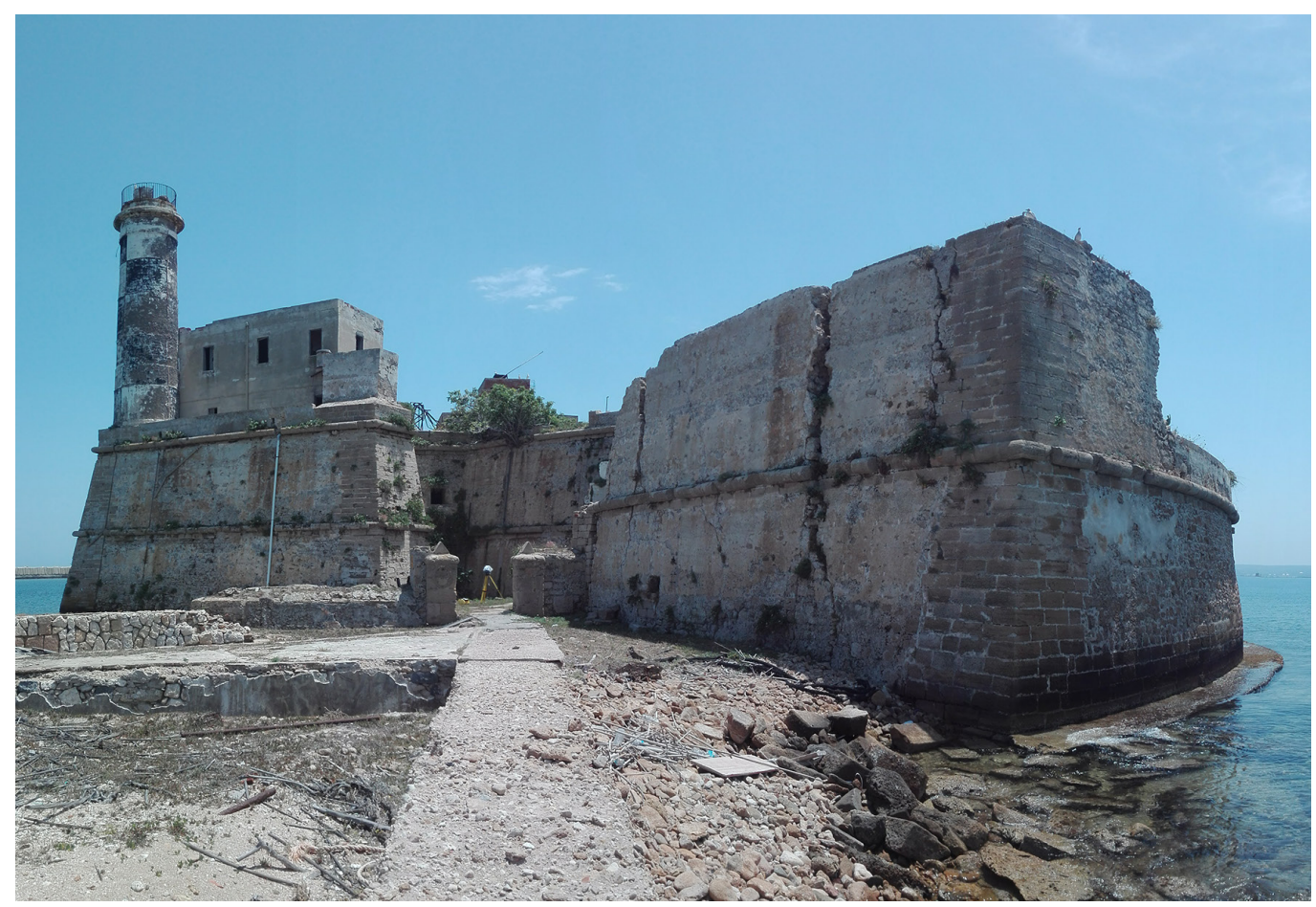


che si affacciano sul mare. L'esigenza di difendere la popolazione e le città siciliane, nel corso dei secoli, ha portato alla realizzazione di una serie di misure di difesa che si articolano lungo la costa, tra queste: le torri di avvistamento, da distinguere dai fari [2] e le piazzeforti [Nucifora 2009, pp. 59-62].

Durante il XVI secolo, in epoca spagnola [Trigilia, Agnello I994, p. 98], tali strutture vennero riorganizzate: sulla costa orientale Messina venne 'collegata' a Milazzo; Augusta e Siracusa vennero raccordate a Malta, che nel 1565 fu assediata dagli ottomani, guidati da Solimano, con l'obiettivo di approdare in Sicilia. Fu grazie all'eroica resistenza dei Cavalieri di Malta che l'assedio falli. I luoghi della difesa della Valletta furono sostanzialmente i tre forti di Sant'Elmo, San Michele e Sant'Angelo, e tra l'altro gli ultimi due furono costruiti durante l'assedio. La costa occidentale era difesa dalle piazzeforti di Trapani, Marsala e Sciacca. A nord Palermo e a sud, sebbene le strutture di difesa non fossero adeguate al XVI secolo si trovava Licata, Agrigento e Gela [Dufour 1992, pp. 12, 14- 17].

II XVI secolo fu anche protagonista dell'evoluzione tecnologica delle armi da fuoco [Mazzarella, Zanca 1985, pp. 103, I04]. Di fatti Augusta, assieme a Siracusa, Catania e Messina, possedevano delle fortificazioni obsolete a causa dell'introduzione di queste nuove armi, considerando soprattutto il fatto che nelle intenzioni dell'impero spagnolo, esse dovevano diventare fortezze baluardo contro l'avanzata del nemico [Dufour 1989, p. 35]. A tale scopo, il governo viceregio spagnolo fece edificare, lungo le coste e non solo, delle piccole fortificazioni i cui tempi di realizzazione erano ben minori di quelli delle piazzeforti, e che in un primo momento resistettero bene agli assalti. Ma la mancata realizzazione di opere difensive più ampie e strutturate ne decretò ben presto il declino [Magnano di San Lio 20 I6, pp. I19-125].

La grande baia di Augusta si componeva di una grande rada a nord, che poteva facilmente ospitare una flotta, limitata a levante dall'isolotto di Avalos, e a ponente di una costiera ricca di corsi d'acqua e coltivazioni che mostrava il fianco ai numerosi incursori. La posizione geografica della città, vicina a Catania, ricca ma poco fortificata e difesa essa stessa solo da un piccolo castello medievale di epoca federiciana, assolutamente inadeguato contro le moderne artiglierie, la esposero alle successive incursioni turche e barbaresche: nel I55 I

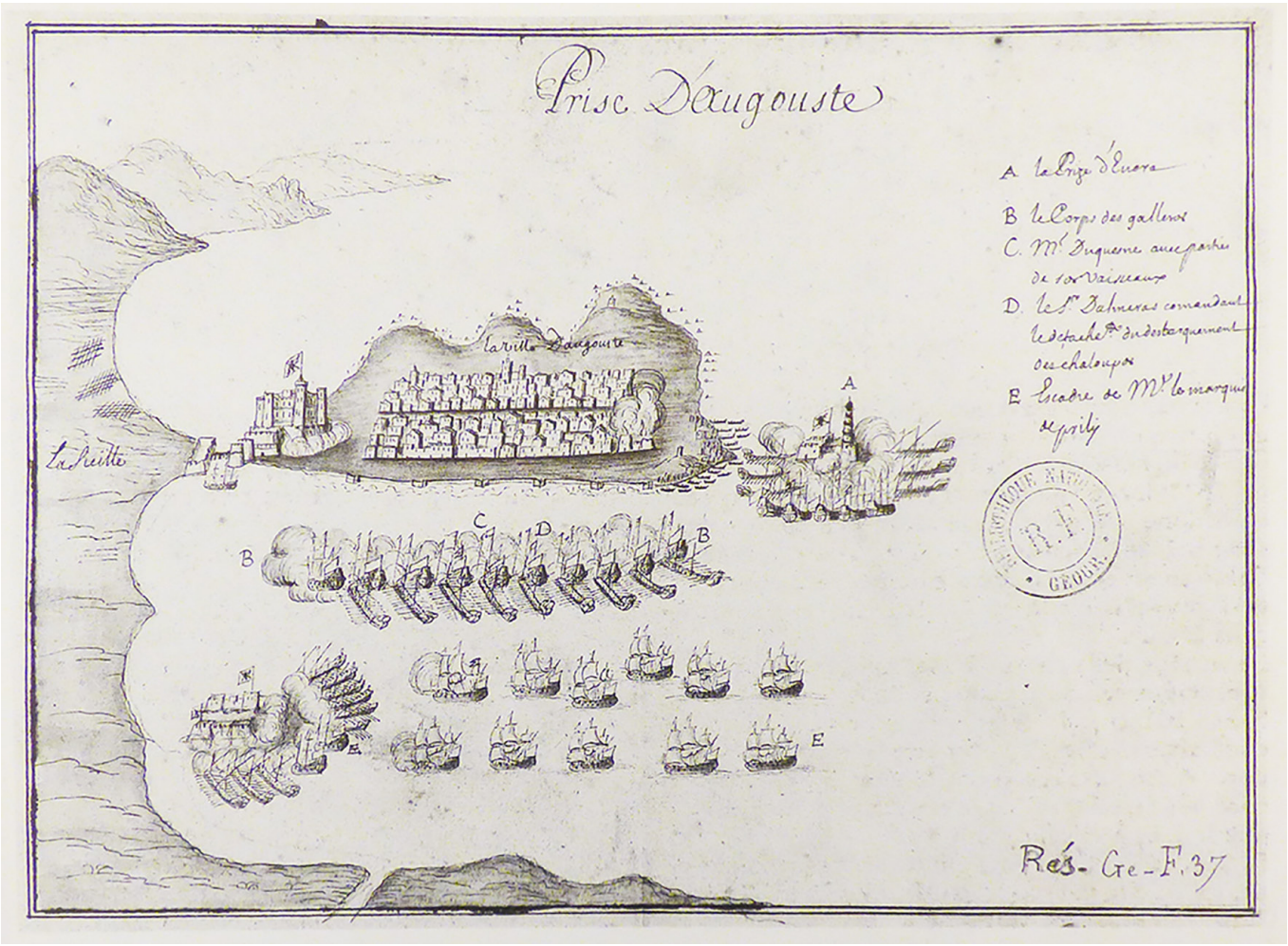



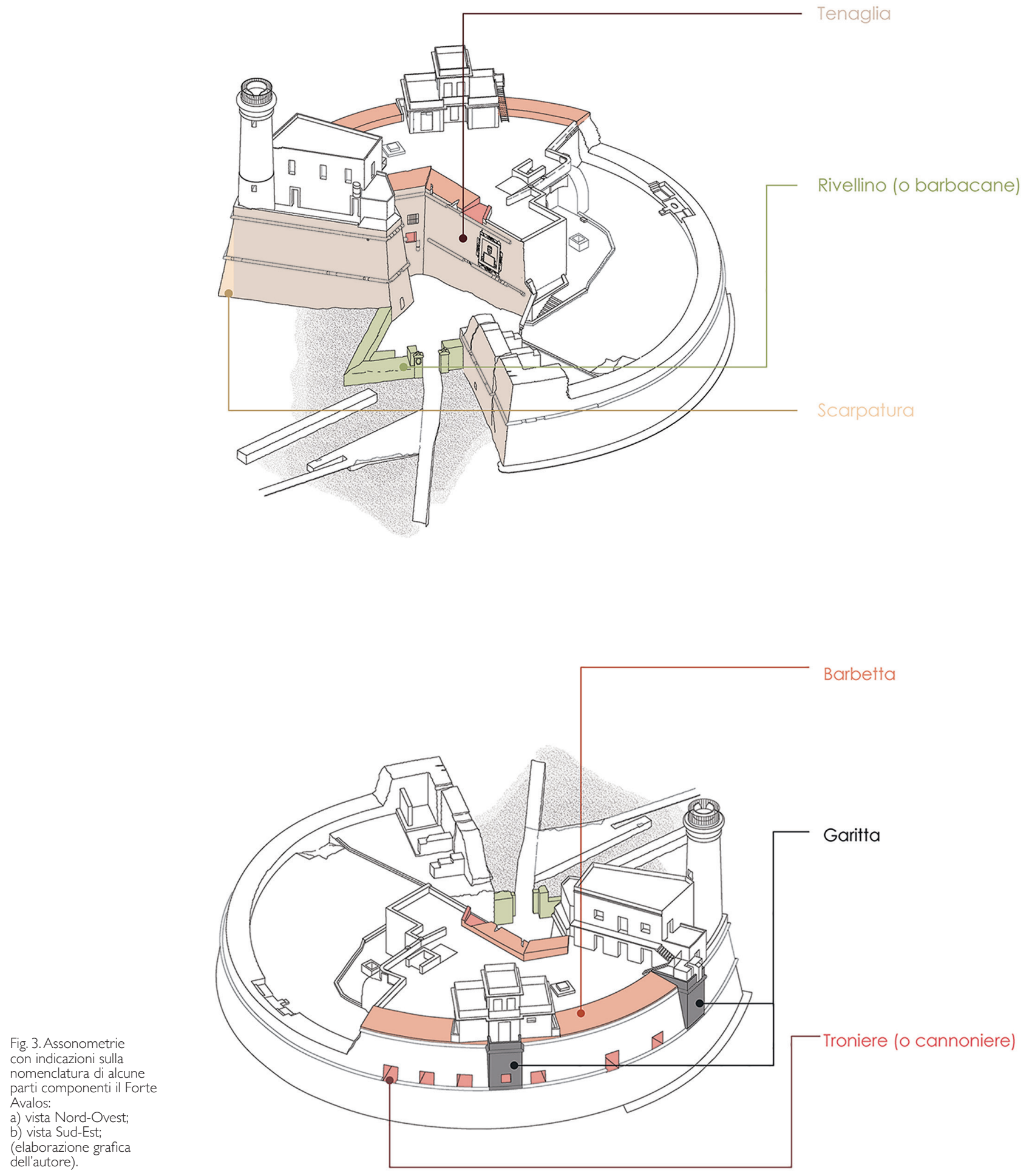
Fig. 4. Andamento della 'tenaglia' e nomenclatura delle parti che la compongono (elaborazione grafica dell'autore). quella di Sinan pascià, nel 1552 fu la volta di Dragut e infine nel I 560 toccò a Piali pascià [Santoro 1985, p. 138].

Fu grazie al comando spagnolo che le operazioni di fortificazione del porto di Augusta subirono un'accelerazione. Nel 1567, per volere del viceré di Sicilia Don Garcia de Toledo, vennero costruiti nel lato nordoccidentale del porto i forti Garcia e Vittoria. Qualche anno più tardi, nel 1570 venne edificato Forte Avalos [Dufour 1996]. A un secolo dalla sua costruzione, le capacità difensive del forte furono messe alla prova, infatti il 17 agosto del 1675, a seguito di una congiura, i francesi comandati da Vivonne si diressero verso Augusta (fig. 2) e posero sotto assedio i tre forti della città fino a giungere al castello. II primo forte

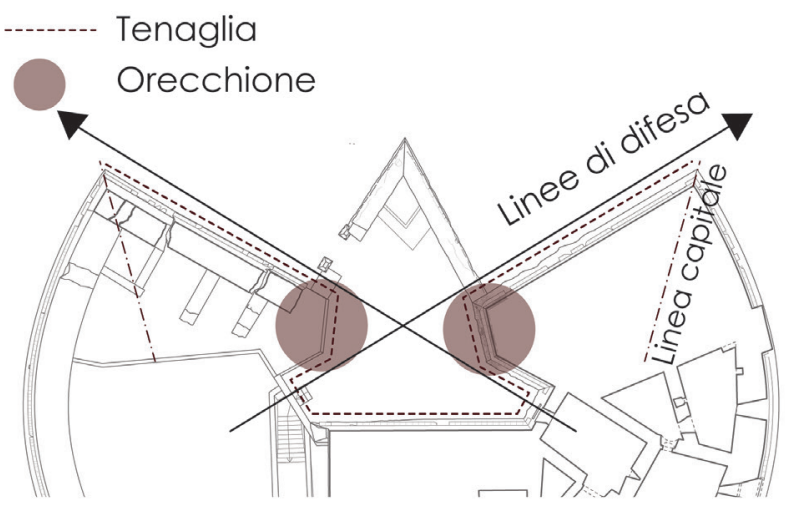

a cadere fu proprio forte Avalos che uscì però indenne da questo scontro [Anonimo I770, pp. 479-483].

Prima di lasciare l'isola nel 1678, i francesi fecero saltare la polveriera di forte Avalos danneggiandolo gravemente. II Viceré Benavides, nel 168 I lo fece 'riedificare' [Anonimo I770, p. 536], anche se è molto più probabile che lo avesse fatto riparare, e vi fece apporre una targa a testimonianza del suo operato.

Tale ricostruzione ebbe vita breve, tanto che a seguito del terremoto del Val di Noto del 1693, così come la città di Augusta subì gravi danni e perdite, anche torre Avalos vide cadere la sua lanterna [Boccone 1697 p. 2I], che fu poi riedificata nel 1740 (notizia gentilmente concessa dal professore Eugenio Magnano di San Lio da documenti inediti).

Un nuovo evento disastroso segnò per sempre la struttura:"Nel 1823 soggiacque all'esplosione della polverista che ne fece saltare la metà del lato del porto, e poi si riparò ad un piano per pezzi da costa scoperti" [Ferraguto 1862, p. 29].

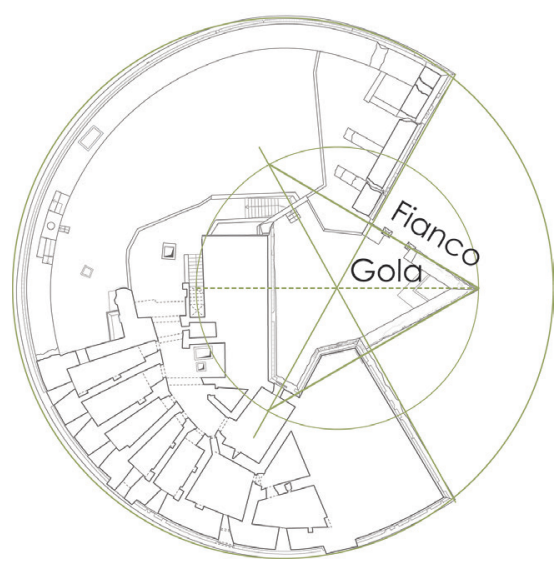



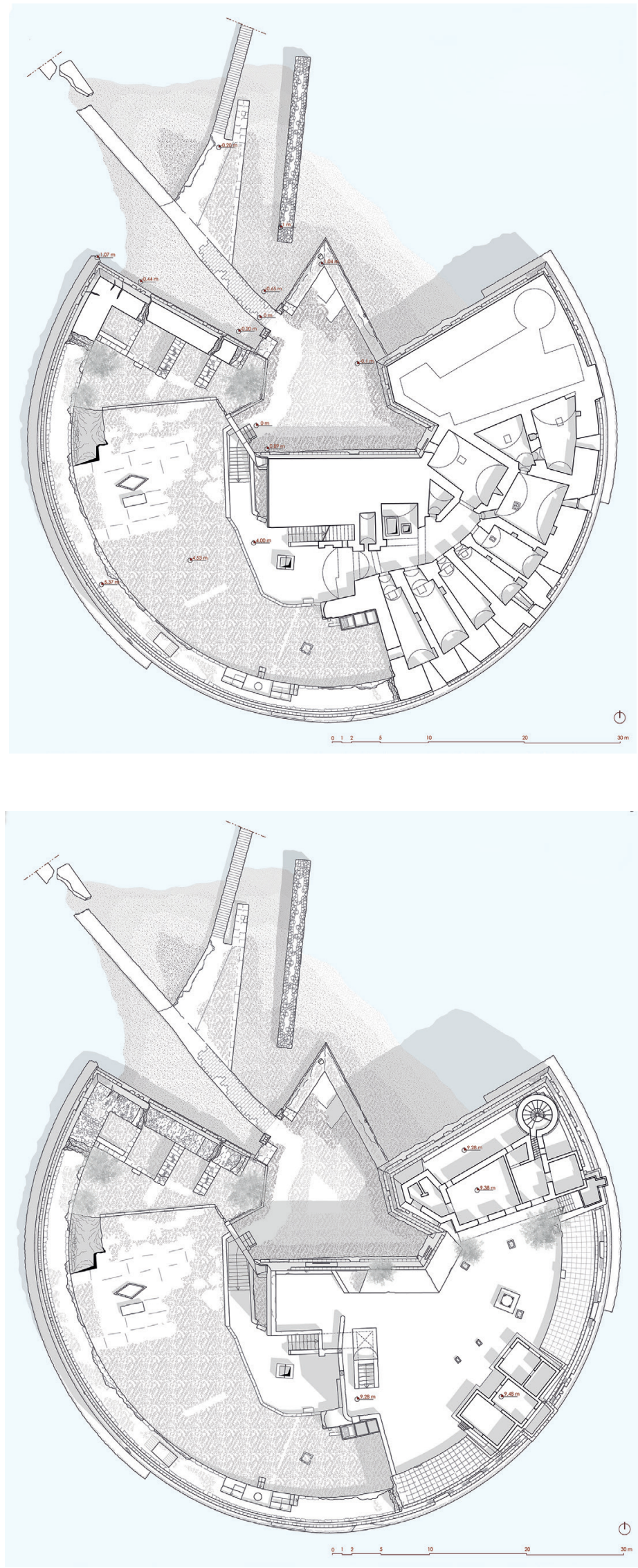
A seguito dell'esplosione venne realizzato un progetto di restauro delle parti superstiti, ma da quel momento in poi la parte danneggiata non venne più ricostruita [Ferraguto I862]. Per aumentare la gittata luminosa del faro, nel I 857 esso venne innalzato: "L'attuale torre non fu quindi costruita ex novo [...]: essa non è che la soprelevazione di questa [...] eseguita dopo essere state risarcite tutte le lesioni causate dall'esplosione della polveriera" [Cacciaguerra 1971, p. 138].

Dalla fine dell' 800 e per tutto il '900 si sono susseguiti interventi di riparazioni e aggiunte non sempre facilmente riscontrabili a livello documentale, mentre dal recente rilievo del 20 I 8, emerge invece un grave stato di dissesto e proprio per questo, assieme al vincolo della zona militare, forte Avalos non è normalmente visitabile.

Attualmente l'unico modo per raggiungerlo è il mare poiché la passerella che lo collegava alla diga foranea e alla terraferma è crollata da qualche anno. Periodicamente vengono organizzate delle visite ai forti del porto, ma a differenza degli altri due, esso resta inaccessibile.

\section{Nomenclatura e descrizione del forte}

"Ogni disciplina, attività, sfera culturale e sociale ha un suo proprio linguaggio specifico, un gergo che certamente si collega alla sfera linguistica generale cui appartiene, ma che se ne distingue sia per l'uso di vocaboli o modi di dire specialistici [...] sia per l'utilizzo di vocaboli comuni in significati diversi da quelli usuali" [Conti 20।8, p. 8].

Il forte di compone di diversi elementi (figg. 3a, 3b) ciascuno con la sua funzione e denominazione: il primo elemento in cui ci si imbatte è la tenaglia (fig. 4), il fronte rivolto verso la terraferma. "La tenaglia era un'opera difensiva costituita da facce che formano un angolo convesso [...] col compito di incrementare la difesa del fossato o a coprire una pusterla" [Maglio,Taddei 2018, p. 92].

Come ulteriore elemento di difesa, addossato al fronte interno della tenaglia, è presente il rivellino (fig. 5), inserito, molto probabilmente in un secondo momento. Si tratta di un'opera fortificata addizionale e avanzata tipica dell'architettura bastionata, con pianta a $\vee$ o a semicerchio, costruita al di fuori della cinta per coprire punti deboli o esposti. Generalmente era più basso della fortificazione stessa ed era eretto davanti a una porta, per difenderla dal fuoco e dai proietti lanciati dal nemico. Si compone di due facce dette 'fianchi' e di una 'gola' vincolata al forte [Maglio,Taddei 2018, p. 75].

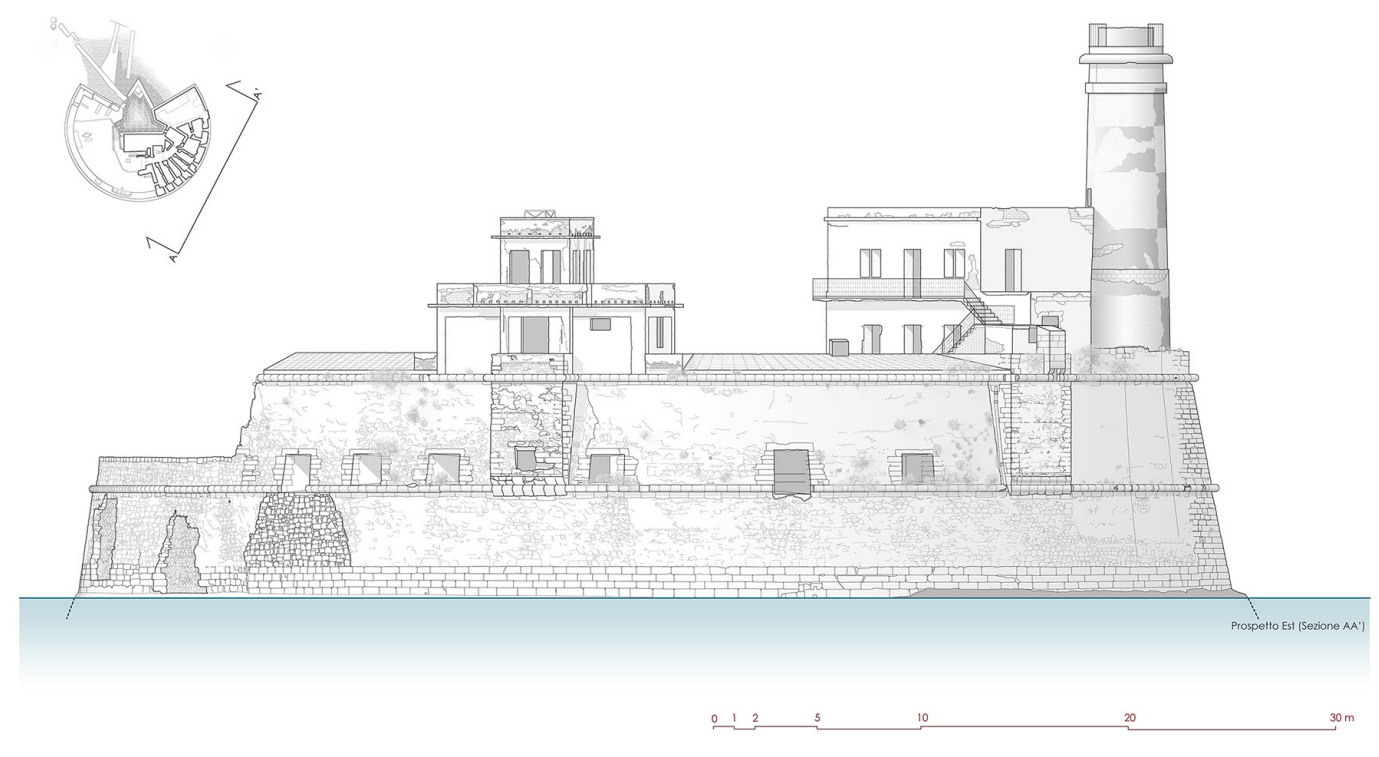


Procedendo, sulla destra è presente un'apertura che dà su una rampa di scale tramite la quale si giunge al primo livello (fig. 6a), che ben mostra le ferite inferte a seguito dell'esplosione del 1823 che demolì quasi metà del forte.

Su questo livello si trovano le troniere o cannoniere in casamatta superstiti atte, un tempo, ad ospitare le bocche dei cannoni, visibili all'esterno tramite delle aperture strombate dotate di un piccolo parapetto, detto 'ginocchiera' [Maglio,Taddei 20 I8, p. 80]. Gli ambienti che ospitavano i cannoni erano coperti da volte a botte dotate di sfiatatoi per i fumi.

Una seconda rampa di scale conduce al secondo livello (fig. 6b) che ospita oltre al faro, due corpi di fabbrica realizzati tra la fine dell' 800 e il '900.

Qui, lungo tutto il perimetro possono ancora scorgersi delle aperture dette troniere in barbetta che sostanzialmente avevano la stessa funzione di quelle poste al livello inferiore, con la differenza di essere all'aperto. Per assorbire gli urti e limitare la proiezione di schegge murarie dovute all'impatto dei proiettili, la 'barbetta', ovvero il massiccio terrapieno che correva lungo il bordo superiore del forte, garantiva maggiore protezione ai militari.

Uno degli accorgimenti utilizzati nelle costruzioni 'alla moderna' e applicato al forte fu quello della 'scarpatura' dei muri, ovvero la caratteristica inclinazione verso l'esterno della base delle mura stesse, attuata per irrobustirle e annullare gli eventuali angoli morti che potevano ostacolare la visuale e quindi la difesa [Maglio,Taddei 20 I, p. 9I].

Fin dalla sua costruzione il forte entra di fatto a far parte delle difese dell'Isola venendo censito dagli ingegneri militariTiburzio Spannocchi nel I578, e Camillo Camilliani nel I583 [Villabianca, 1986, pp. 30, 3I], così come testimoniato dalle loro bellissime tavole redatte in occasione della ricognizione delle difese del Regno. In entrambe è possibile vedere il faro raffigurato come una colonna tortile, probabilmente per la collocazione esterna delle scale, tale particolarità la fece definire da Jouvin uno dei "pezzi rari d'Italia" [Dufour 1992, p. 39].

Già da tempo però la funzione difensiva del forte si è esaurita, l'unico ricordo che oggi resta di quella grandezza sono le mura, in parte crollate e invase dalla vegetazione e il faro, dismesso nel 1934 e ormai in disuso che guarda il porto, e quasi si confonde con le ciminiere della zona industriale e i fumaioli delle navi militari e petroliere che vi transitano (figg. 7,8$)$.

\section{Conclusioni}

Per quanto un bene architettonico entri a far parte dell'immaginario collettivo, diventando quasi un simbolo, non si può non tenere conto del fatto che sia il tempo, le intemperie, eventi eccezionali potrebbero comprometterlo, se non addirittura distruggerlo.

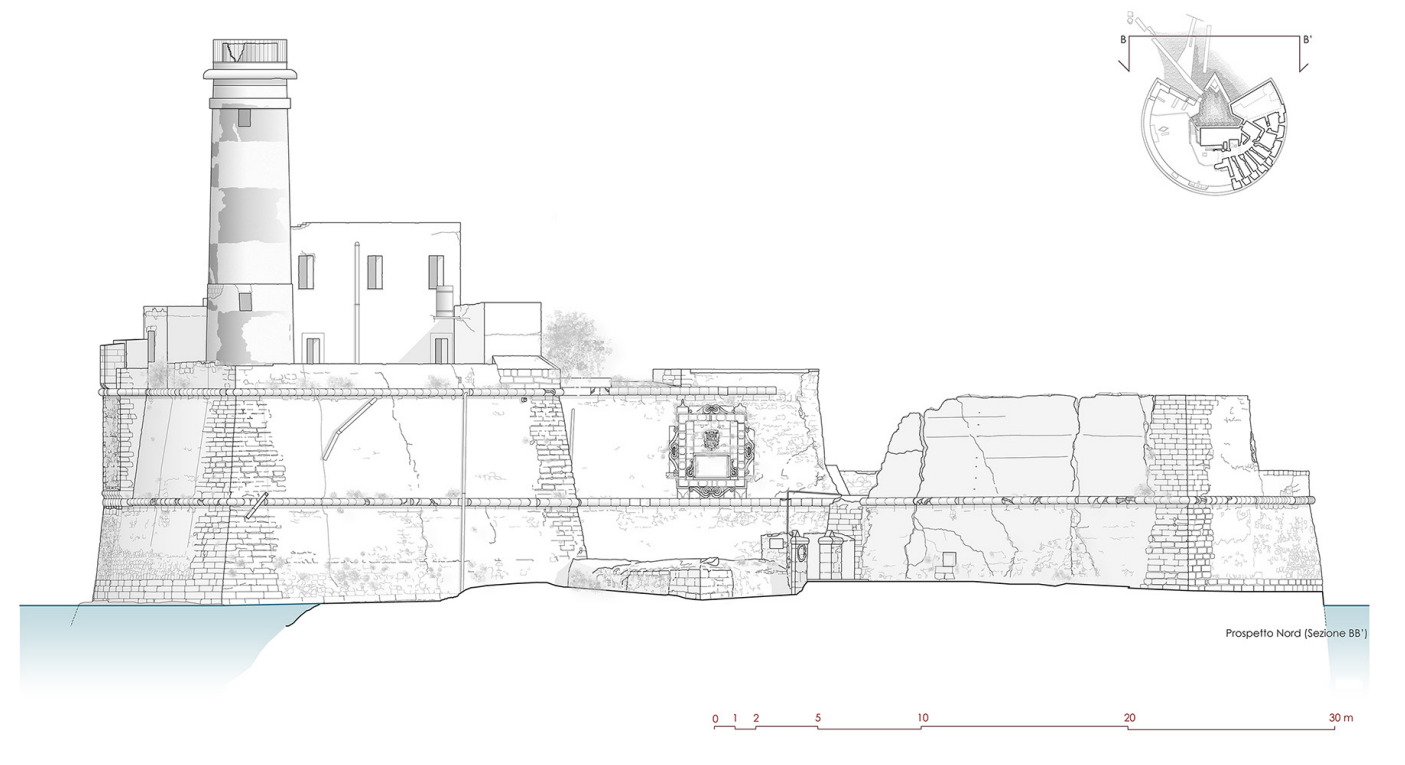


D'altro canto, lo stesso oggetto della conservazione, per essere colto, per quanto possibile, nei suoi vari aspetti, necessita della concorrenza di più punti di vista soggettivi e di diversi approcci scientifici, poiché come ci ricorda il filosofo Sini:" quando affermo che la verità è 'relativamente assoluta' intendo dire che la ricerca della verità, alla quale non possiamo rinunciare, avviene sempre all'interno di una relazione. E la verità, essendo a sua volta dinamica, suscita in noi un dovere morale, un'interrogazione ininterrotta che non può mai accontentarsi di un sapere particolare" [Sini 20।8].

Molte sono infatti le discipline che concorrono alla preservazione non solo della materia in sé, ma anche della memoria di come un bene architettonico sia cambiato e sia stato percepito nel tempo. Dalla fotografia al rilievo e la sua restituzione grafica, fino alla costruzione di modelli tridimensionali, ciascuno con le proprie potenzialità e limiti.

In questo testo si è proposta la restituzione del rilievo, condotto in buona parte attraverso la stazione totale, integrando ove possibile con il rilievo diretto, come una delle possibili strade per la creazione di una memoria se pur parziale, che si è di fatto appoggiato non solo alla fotografia ma anche allo studio di disegni storici dando una possibile prospettiva attuale fondendo il qui e ora del rilievo e le tracce storiche reperite nella ricerca. Per questo anche il rilievo e la restituzione grafica possono concorrere alla costruzione della memoria di un oggetto architettonico e in un certo senso evitare che esso, venendo dimenticato, scompaia definitivamente. Inoltre, attraverso lo studio della documentazione storica è possibile rintracciare il suo mutare nel tempo e a volte anche il perché di tali cambiamenti. Mentre con il rilievo e la rappresentazione si fornisce una visione del suo stato attuale, perché come afferma Purini: "Rappresentare è pensare e costruire simulacri. Simulacri di ciò che esiste, di ciò che è esistito e che non esiste più, di ciò che non è più come fu all'inizio della sua esistenza $\mathrm{o}$ in qualche altra sua fase e che vuole essere restituito alla sua immagine primaria". [Purini 1999, p.10].

A conclusione, si desidera evidenziare un aspetto non secondario di cui non si è parlato, ma che sta molto a cuore a chi scrive e agli abitanti di Augusta è che il tratto di mare su cui insiste forte Avalos è carico di accezioni negative, vi si affaccia infatti la zona industriale tra Augusta e Siracusa che tanti mali ha portato all'ambiente e alla popolazione, ma nonostante ciò esso, metaforicamente, assume in sé entrambe le caratteristiche delle fonti dell'oracolo di Trofonio. Da un lato come Lete lo ha isolato della terraferma rendendone difficile l'accesso e salvo alcune eccezioni ne ha quasi fatto dimenticare la sua esistenza, dall'altro però come Mnemosine, lo ha preservato da eccessive manomissioni, bloccandolo in una dimensione quasi atemporale.

\section{Note}

[I] Tratto dalla tesi di laurea in Architettura di Eleonora Di Mauro, Forte Avalos: un relitto di pietra, rilievo, indicazioni di restauro e riuso. A.A. 2018/2019, Università degli Studi di Catania. Relatore prof. Eugenio Magnano di San Lio, correlatrice prof.ssa Maria Rosaria Vitale.

[2] Come afferma Nucifora, tra le torri di avvistamento e i fari è sempre esistita un'antinomia, in riferimento alla loro funzione e alla direzione in cui le informazioni dal o per il mare erano, tramite essi, veicolate.

\section{Riferimenti bibliografici}

Anonimo (1770). Raccolta di tutti i più rinomati scrittori dell'storia generale del Regno di Napoli. Tomo X. Napoli: Stamperia di Giovanni Gravier. 1770.

Don Boccone Paulo, Don Boccone Silvio ( 1697$)$. Museo di Fisica e di esperienze Variato e decorato di osservazioni naturali e note Medicinali, e Ragionamenti secondo Prinicipii de' Moderni.Venezia. 1697.

Cacciaguerra Vincenzo (197I). La lanterna di torre Avalos. In Notiziario storico di Augusta, 6, dicembre 1971, pp. I35- 68.

Cardaci Alessio, Versaci Antonella (2013). L'innovazione del rilievo fotografico per la conoscenza, la documentazione e fruizione dei beni culturali. In DisegnareCon, 12, 2013,6, pp. I- I0.

Conti Flavio (20 I8). Prefazione. In Maglio Luigi, Taddei Domenico (a cura di). Le parole del castello, nomenclatura castellana. Napoli: Giannini. 
Dufour Liliane (1992). Atlante storico della Sicilia, le città costiere nella cartografia manoscritta 1500-1823. Palermo: Arnaldo Lombardi. pp. $14-17$

Dufour Liliane (1989). Augusta da città imperiale a città militare. Palermo: Sellerio.

Ferraguto Luciano (1862). Augusta di Sicilia al Parlamento italiano memoria dellingegnere civile dottor Luciano Ferraguto. Catania:Tipografia F.lli Pastore.

Maglio Luigi, Taddei Domenico (a cura di). (20 I 8). Le parole del castello, nomenclatura castellana. Napoli: Giannini.

Magnano di San Lio Eugenio (2016). The "spanish school" bastion defence. In Giorgio Verdiani (ed.). Defensive architecture of the Mediterranean XV to XVIII century. Firenze: Didapress. vol 3, pp. I 19- I 26.

Mazzarella Salvatore, Zanca Renato (1985). Il libro delle torri. Le torri costiere di Sicilia nei secoli XVI-XX. Palermo: Sellerio. pp. 103,104

Nucifora Sebastiano (2005). Sul limitare. In Bartolomei Cristiana, Amoruso Giuseppe (a cura di). L'architettura dei fari italiani. Firenze: Alinea, 2005, volume IV, pp. 256.

Purini Franco (1999). Costruire lo sguardo. In XY, 35-36-37, 1999, pp. I0- I I.

Santoro Rodo (1985). La Sicilia dei castelli: la difesa dell'isola dal VI al XVIII secolo, storia e architettura. Edizioni Pegaso s.r.l.

Sini Carlo (20 I8). La verità? Sta sempre nella relazione. In Avvenire.it, 29 marzo 20 I 8. <https://www.avvenire.it/agora/pagine/ carlo-sini-filosofo-intervista>.

Trigilia Lucia, Agnello Giuseppe (1994). La spada e l'altare: architettura militare e religiosa ad Augusta dall'età sveva al Barocco. Palermo: Arnaldo Lombardi.

Villabianca Francesco Maria Emanuele e Gaetani (marchese di), (1986). Torri di guardia dei litorali della Sicilia (a cura di Salvo Di Matteo). Palermo: Edizioni Giada.

Vita Francesco (1996). Inesto istorico della città di Augusta 1653 (a cura di Dufuor Liliane). Siracusa: Arnaldo Lombardi Promozione.

\section{Autore}

Eleonora Di Mauro, Università degli Studi di Palermo, eleonora.dimauro@unipa.it

Per citare questo capitolo: Di Mauro Eleonora (2020). Forte Avalos: tra memoria e oblio, un disegno per ricordare/Fort Avalos: memory and oblivion, a drawing to remember. In Arena A., Arena M., Brandolino R.G., Colistra D., Ginex G., Mediati D., Nucifora S., Raffa P. (a cura di). Connettere. Un disegno per annodare e tessere. Atti del $42^{\circ}$ Convegno Internazionale dei Docenti delle Discipline della Rappresentazione/Connecting. Drawing for weaving relationships. Proceedings of the 42th International Conference of Representation Disciplines Teachers. Milano: FrancoAngeli, pp. 2098 -2 1 I7. 


\title{
Fort Avalos: Memory and Oblivion, a Drawing to Remember
}

\author{
Eleonora Di Mauro
}

Abstract

In 16 th century Sicily, in order to deal with the incursions of the Turks and Barbary, the Spanish viceroy government put in place the construction of some maritime forts in order to defend the coasts of the island. Among these, in the port city of Augusta, Avalos fort was built around 1570, a small modern fortification characterized by the particular semicircular floor plan, capable of having a wide radius of action. Various and extensive studies have been conducted on the events and historical representations of the fort also in relation to the fortified maritime system of the Sicilian coasts. However, these studies have not always been related to the actual state of the property, which, rising in the middle of the military zone and on an islet, is not easy to reach, much less to measure. With the help of modern and sophisticated tools, in similar cases, many difficulties can be overcome. In this specific case, the survey was carried out by means of the total station, from which a state of severe deterioration emerged with serious structural failures. The delays in the consolidation and restoration of the asset risk leading to destruction, through this work it is therefore proposed to leave at least a trace of an architectural asset that is physically disappearing, making use of the connection between various techniques and resources in view of the construction of a memory that has a visual, metric and historical consistency.

Keywords

documentation, forts, fort Avalos, representation, virtuality.

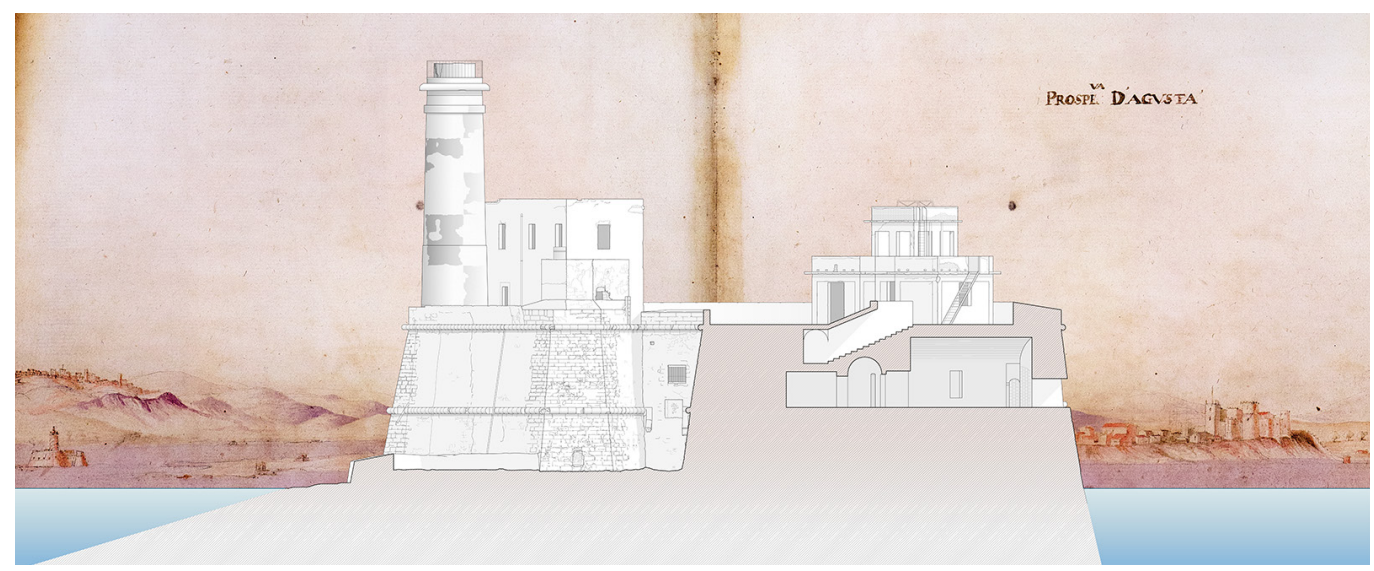




\section{Introduction}

The vast Italian architectural heritage if on the one hand makes our country unique, on the other it generates the continuous request for resources to be used for maintenance, and in cases of serious instability, for restoration and for interventions aimed at its conservation; such operations, understood in the material sense of the term, are not always possible for various reasons.

There are cases in which it is the environment itself, in which a certain architectural structure arises, which dictates stringent constraints for its maintenance, others in which the conflicts between the various entities, which vie for or shift the responsibility of management, make exhausting conservation attempts, thus abandoning them to ruin, causing them to fall into oblivion.

Already in the mid- I800s, thanks also to the advent of photography, the need arose to create a memory of the architectural heritage. The work of the Alinari brothers, who over time have built a photographic collection that has many specimens [Cardaci,Versaci 20I3] is a very clear example. This was dictated by the growing awareness that in the event of a disaster or the natural degradation of the architectural asset, in the absence of a database, not only the material but also the memory of the asset would be lost.

On the south-east coast of Sicily, as in many other parts of southern Italy, there is no shortage of examples of architectural assets that are in state of serious degradation. Some of them are even incorporated in industrial areas, so even reaching them and therefore counting them becomes almost impossible.

In this case it is possible to include a small maritime fortification, located in the Augusta harbor, in the middle of the military zone, Avalos fort (fig. I) which together with Garcia and Vittoria forts constituted a first attempt to adapt the defenses to the 16th century standards [I].

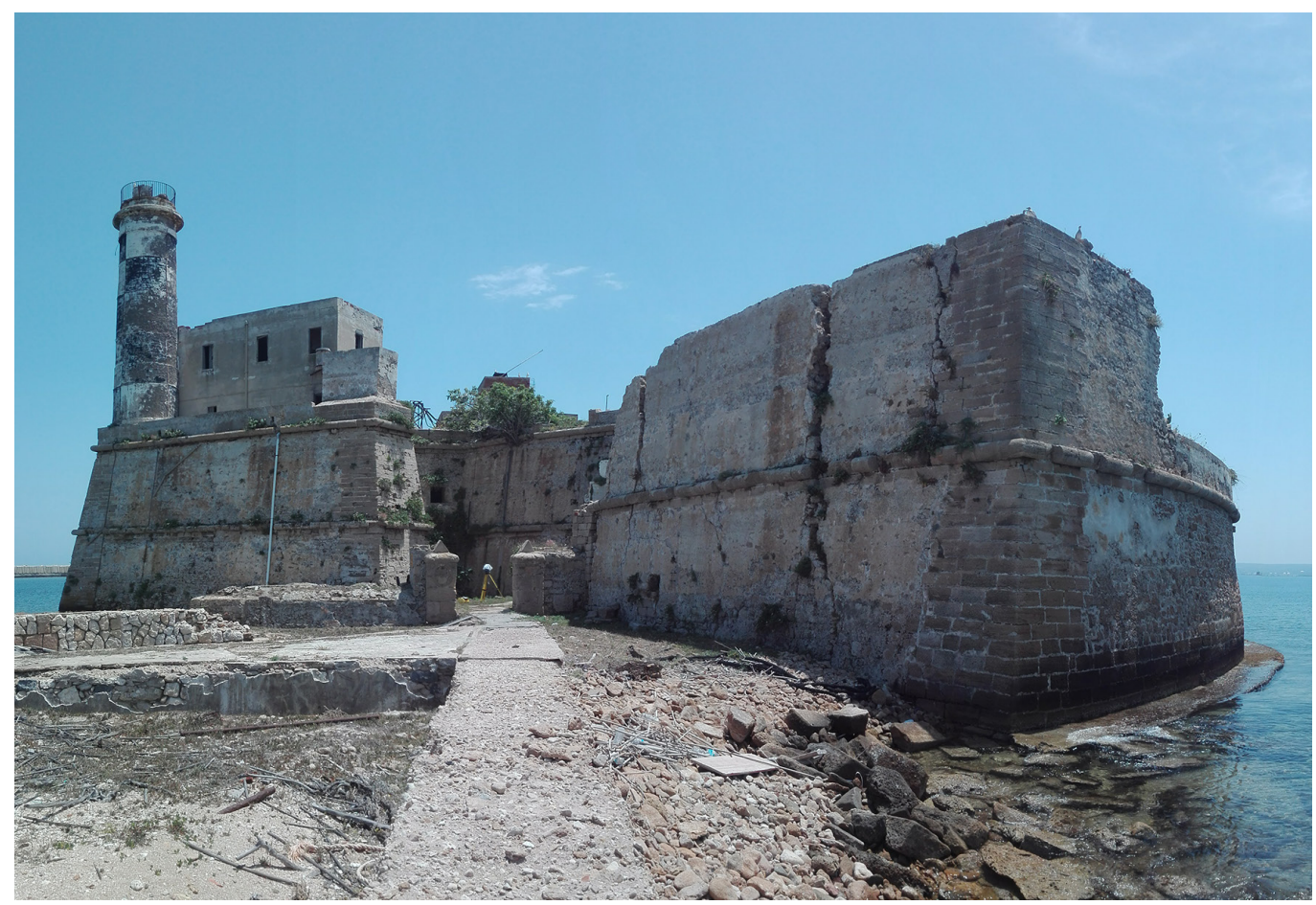




\section{Historical events}

Sicily, due to its geographical location in the center of the Mediterranean, has always represented a pole of trade and commercial, cultural and preferential access routes to Europe. This made it the object of expansionist aims of empires and peoples overlooking the sea. The need to defend the Sicilian population and cities, over the centuries, has led to the creation of a series of defense measures that are articulated along the coast, among them: the watchtowers to be distinguished from the lighthouses [2], and the strongholds [Nucifora 2009, pp. 59-62].

During the 16th century, in Spanish times [Trigilia, Agnello 1994, p. 98], these structures were reorganized: on the east coast Messina was connected to Milazzo; Augusta and Syracuse were connected to Malta, which in 1565 was besieged by the Ottomans, led by Suleiman, with the aim of landing in Sicily. Thanks to the heroic resistance of the Knights of Malta, the siege failed. The places of defense of Valletta were basically the three forts of Sant'Elmo, San Michele and Sant'Angelo, and among other things, the last two were built during the siege. The west coast was defended by the strongholds of Trapani, Marsala and Sciacca. To the north of Palermo and south, although the defense structures were not adequate for the I6th century, Licata, Agrigento and Gela were found [Dufour 1992, pp. I2, I4- I7].

The 16th century was also the protagonist of the technological evolution of firearms [Mazzarella, Zanca 1985, pp. 103, 104]. In fact Augusta, together with Syracuse, Catania and Messina, possessed obsolete fortifications due to the introduction of these new weapons, especially considering that in the intentions of the Spanish empire, they had to become bulwark fortresses against the advance of the enemy [Dufour 1989, p. 35]. For this purpose, the Spanish viceroy government had small fortifications built along the coasts and beyond, whose construction times were much less than those of the strongholds, and which at first resisted the assaults well. But the failure to carry out more extensive and structured defensive works soon led to their decline [Magnano di San Lio 2016, pp. I 19-125].

The large bay of Augusta consisted of a large bay in the north, which could easily host a fleet, limited to the east by the islet of Avalos, and to the west of a coast rich in waterways

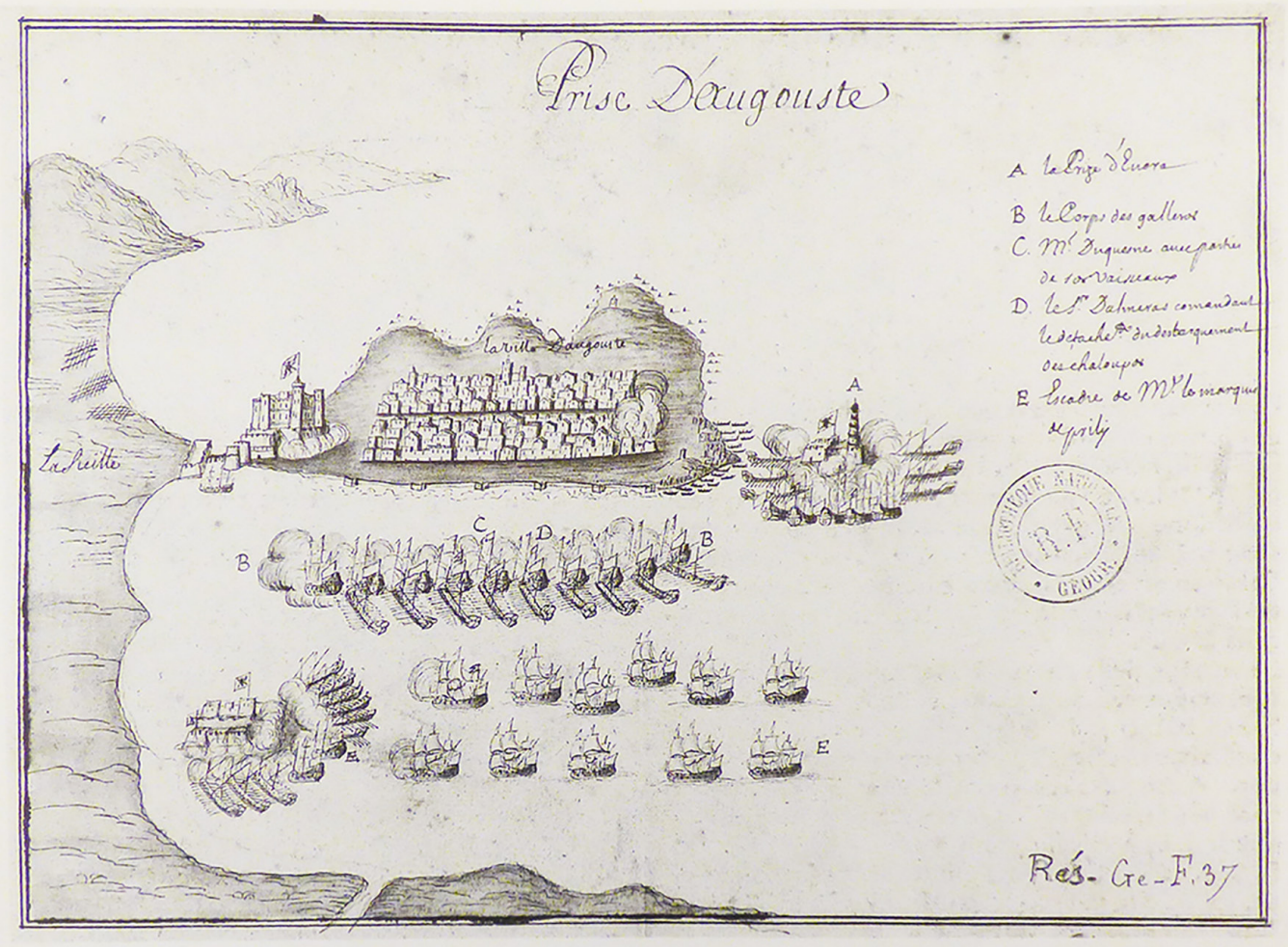



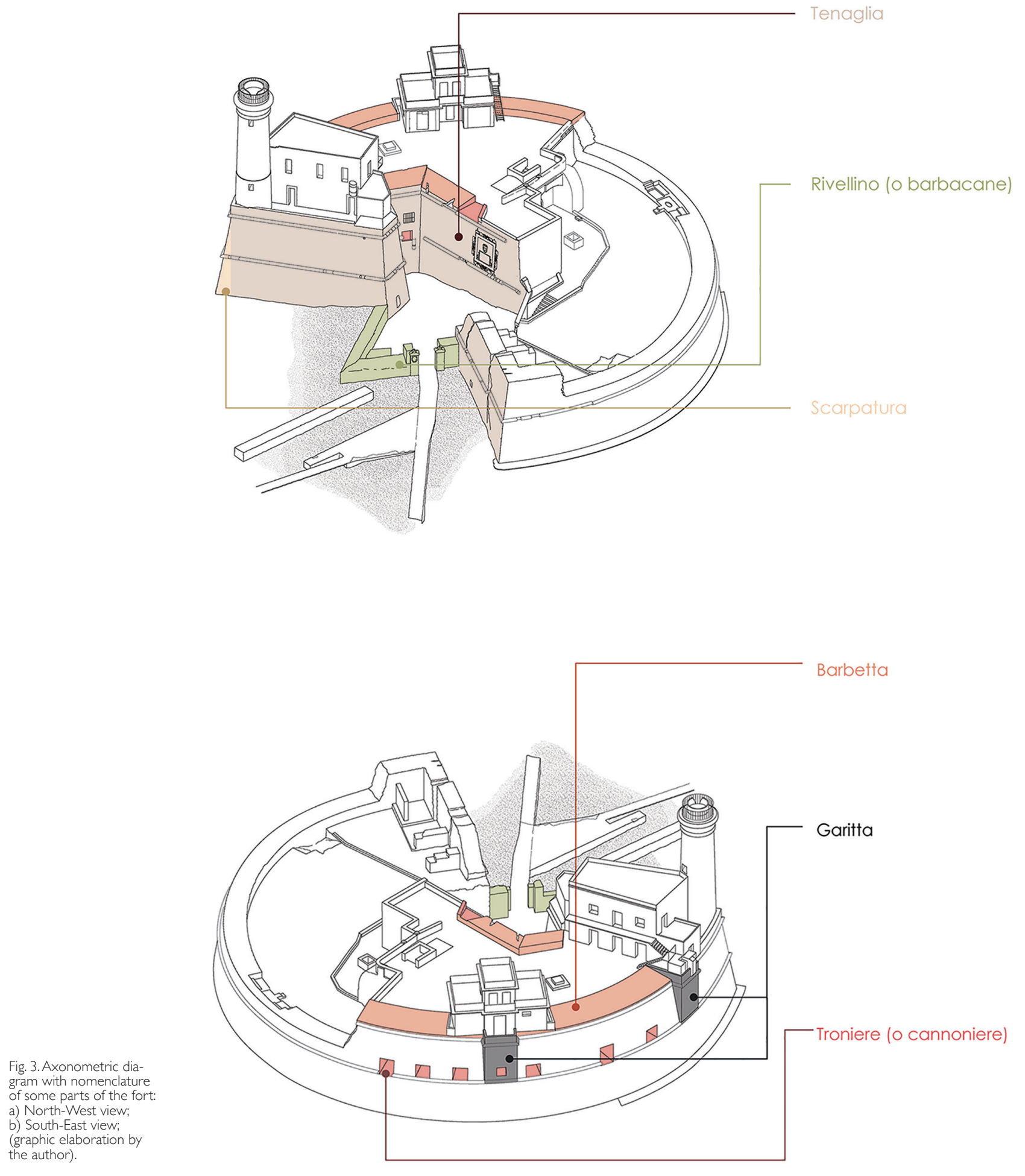
Fig. 4. Tenaille scheme and names of its parts (graphic elaboration by the author). and crops that showed the side to the numerous raiders. The geographic position of the city, close to Catania, rich but little fortified and defended itself only by a small medieval castle from the Federician era, absolutely inadequate against modern artillery, exposed it to subsequent Turkish and Barbary raids: in 155 I that of Sinan pasha, in 1552 it was the turn of Dragut and finally in 1560 it fell to Piali pasha [Santoro 1985 p. I38].

It was thanks to the Spanish command that the fortification operations of the port of Augusta accelerated. In 1567, at the behest of the Viceroy of Sicily Don Garcia de Toledo, forts Garcia and Vittoria were built on the northwestern side of the port. A few years later, in I570 Forte Avalos was built [Dufour 1996]. A century after its construction, the defensive

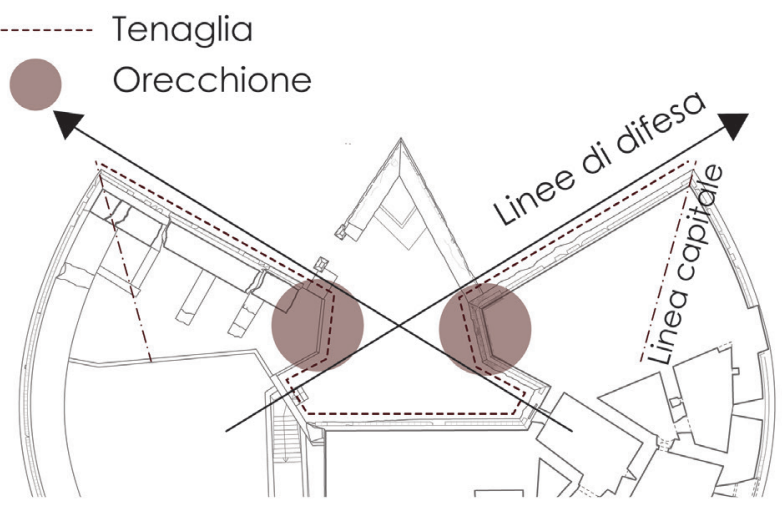

capabilities of the fort were put to the test, in fact on August 17, 1675, following a conspiracy, the French commanded by Vivonne headed towards Augusta (fig. 2) and besieged the three forts of the city up to the castle. The first fort to fall was precisely Avalos, which however emerged unscathed from this clash [Anonymous 1770, pp. 479-483].

Before leaving the island in 1678, the French blew up the powder keg of fort Avalos and seriously damaged it. Viceroy Benavides, in 168I had it rebuilt [Anonymous 1770, p536], although it is much more likely that he had it repaired, and had a plaque affixed to it as proof of his work.

This reconstruction was short-lived, so much so that following the $1693 \mathrm{Val}$ di Noto earthquake, as well as the city of Augusta suffered serious damage and loss, the Avalos tower also saw its lantern fall [Boccone 1697 p. 2 I], which was later rebuilt in 1740 (news courtesy of Prof. Eugenio Magnano of San Lio from unpublished documents).

A new disastrous event marked the structure forever:

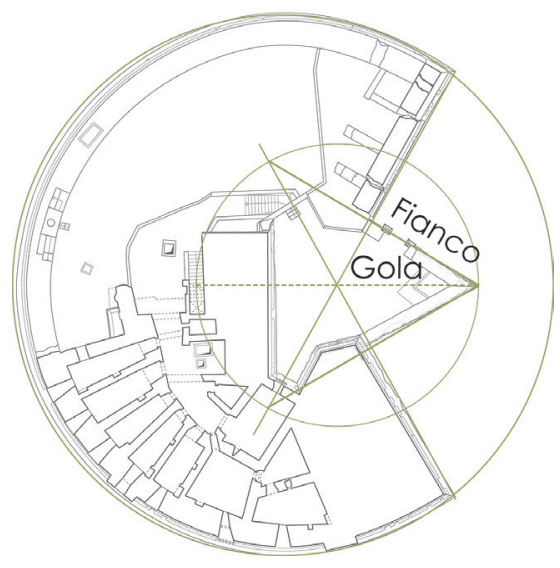



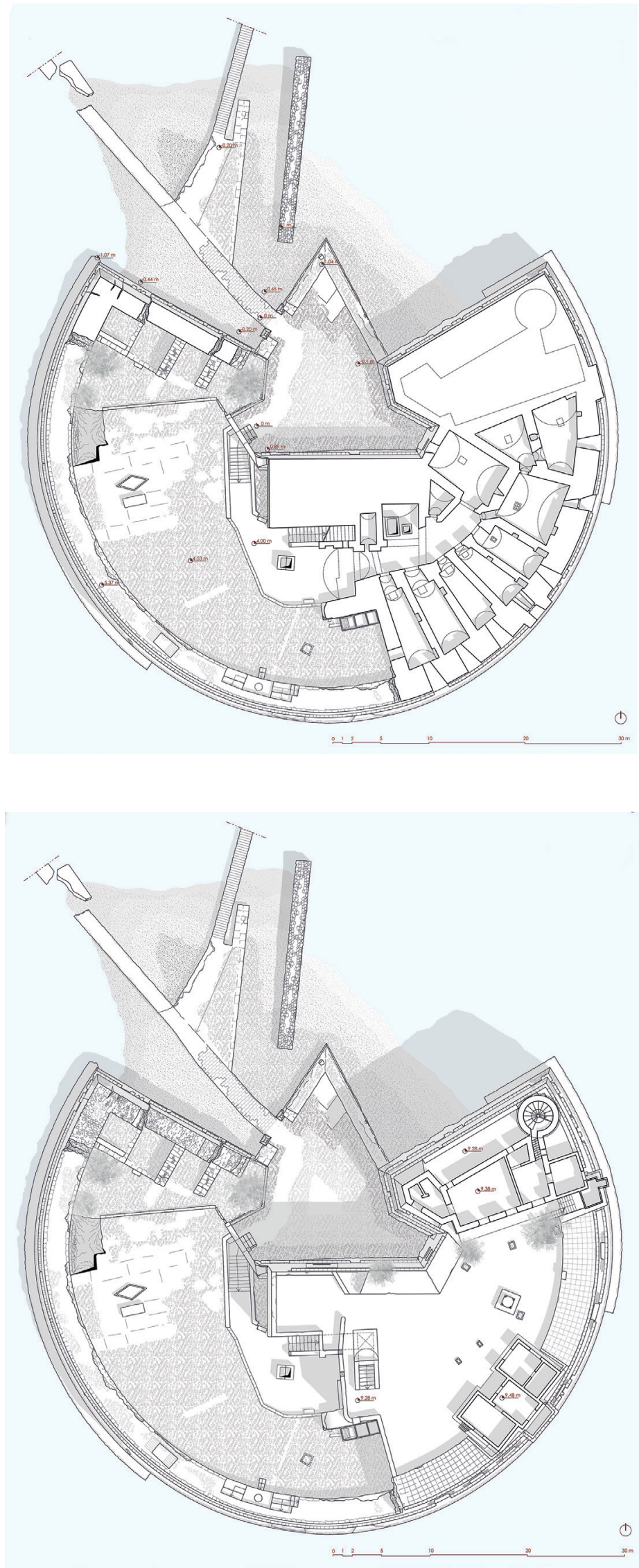
"Nel I 823 soggiacque all'esplosione della polverista che ne fece saltare la metà del lato del porto, e poi si riparò ad un piano per pezzi da costa scoperti" [Ferraguto I862, p. 29].

Following the explosion, a restoration project was carried out on the surviving parts, but from that moment on the damaged part was no longer rebuilt [Ferraguto |862].

To increase the light output of the lighthouse, in 1857 it was raised: "L'attuale torre non fu quindi costruita ex novo, [...]: essa non è che la soprelevazione di questa [...] eseguita dopo essere state risarcite tutte le lesioni causate dall'esplosione della polveriera" [Cacciaguerra I 97 I, p. 138].

Since the end of the 19th and throughout the 20th century, repairs and additions have occurred but they are not always easily documented, while the recent survey of 2018 reveals a serious state of instability and precisely for this reason, together with the constraint of the military zone, fort Avalos isn't normally open to visitors.

Currently the only way to reach it is the sea since the walkway that connected it to the breakwater and the mainland has collapsed for a few years. Visits to the forts of the port are periodically organized, but unlike the other two, it remains inaccessible.

\section{Nomenclature and description of the fort}

"Ogni disciplina, attività, sfera culturale e sociale ha un suo proprio linguaggio specifico, un gergo che certamente si collega alla sfera linguistica generale cui appartiene, ma che se ne distingue sia per l'uso di vocaboli o modi di dire specialistici [...] sia per l'utilizzo di vocaboli comuni in significati diversi da quelli usuali' [Conti 20 I8, p. 8].

The fort is made up of several elements (figs. 3a, 3b), each with its function and denomination: the first element you come across is the tenaille (fig. 4), the front facing the mainland. "La tenaglia era un'opera difensiva costituita da facce che formano un angolo convesso [...] col compito di incrementare la difesa del fossato o a coprire una pusterla" [Maglio, Taddei 20I8, p. 92].

As a further element of defense, leaning against the internal front of the tenaille, there is the ravelin (fig. 5), inserted, most likely at a later time. It is an additional and advanced fortified work typical of the bastioned architecture, with $\mathrm{V} \vee$ or semicircle plan, built outside the walls to cover weak or exposed points. It was generally lower than the fortification itself and was erected in front of a door, to defend it from fire and projectiles thrown by the enemy. It

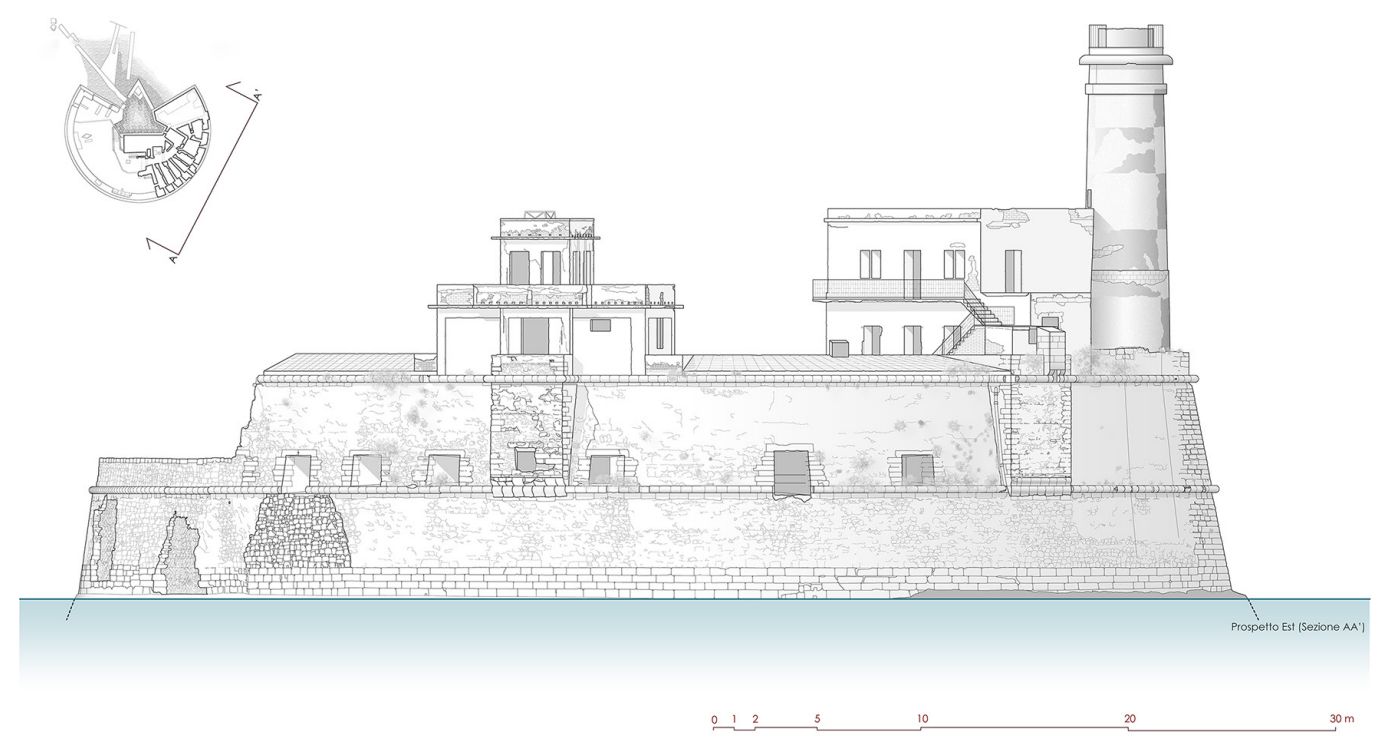


consists of two faces called fianchi and a gola bound to the fort [Maglio, Taddei 20 I8, p. 75]. Proceeding, on the right there is an opening that gives on a flight of stairs through which you reach the first level (fig. 6a), which clearly shows the wounds inflicted following the explosion of I 823 which demolished almost half of the fort.

On this level are the surviving troniere or gunners in casemates, once able to house the cannon's mouths, visible from the outside through splayed openings equipped with a small parapet, called the knee brace [Maglio, Taddei 2018, p. 80]. The rooms that housed the cannons were covered by barrel vaults equipped with vents for the fumes.

A second flight of stairs leads to the second level (fig. 6b) which houses, besides the lighthouse, two buildings built between the end of the 1800s and the 1900s.

Here, along the entire perimeter, you can still see the openings called troniere in barbetta which basically had the same function as those located on the lower level, with the difference of being outdoors. To absorb shocks and limit the projection of wall fragments due to the impact of bullets, the beard, or the massive embankment that ran along the upper edge of the fort, guaranteed greater protection for the military.

One of the tricks used in modern constructions and applied to the fort was that of the scarpatura of the walls, that is the characteristic inclination towards the outside of the base of the walls, implemented to strengthen them and cancel any blind spots that could obstruct the view and hence defense [Maglio, Taddei 20I8, p. 9I].

Since its construction, the fort actually became part of the defenses of the island, being surveyed by the military engineers Tiburzio Spannocchi, in 1578, and Camillo Camilliani, in I 583 [Villabianca, 1986, pp. 30, 3 I], as evidenced by the their beautiful tables drawn up on the occasion of the recognition of the Kingdom's defenses. In both it is possible to see the lighthouse depicted as a twisted column, probably due to the external location of the stairs, this particularity made it one of "pezzi rari d'ttalia" by Jouvin [Dufour, I992 p. 39].

The defensive function of the fort has been exhausted long time ago and the only memory that remains of that magnitude today is the walls, partially collapsed and invaded by vegetation and the lighthouse, abandoned in 1934 and now in disuse looking at the port, and it is almost confused with the chimneys of the industrial area and the smokestacks of the military ships and oil tankers that pass through them (figs. 7, 8).

\section{Conclusions}

As much as an architectonic structure becomes part of the collective imagination, becoming almost a symbol, some elements should be taken into account like time, bad weather, exceptional events that could compromise it, if not even destroy it.

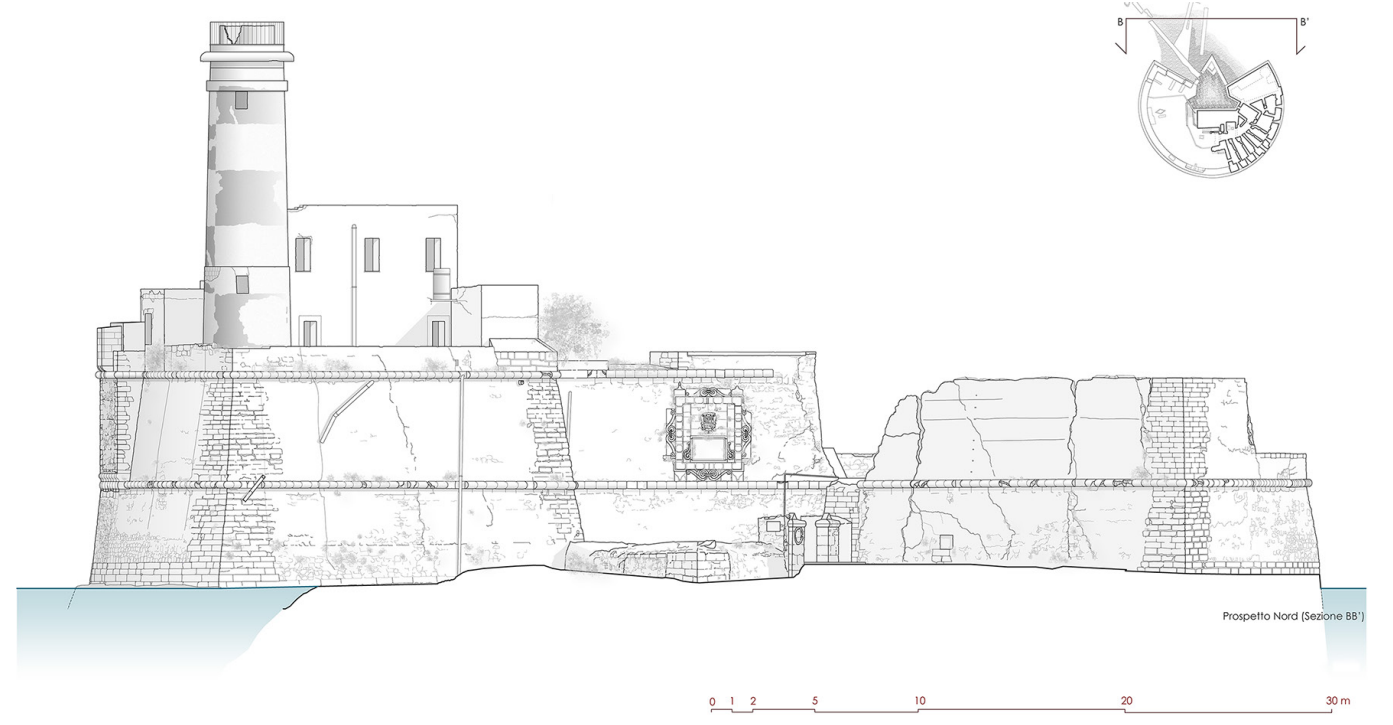


On the other hand, in order to be captured, as far as possible, in its various aspects, the same object of conservation requires the competition of multiple subjective points of view and of different scientific approaches, since as the philosopher Sini reminds us:

"Quando affermo che la verità è 'relativamente assoluta? intendo dire che la ricerca della verità, alla quale non possiamo rinunciare, avviene sempre all'interno di una relazione. E la verità, essendo a sua volta dinamica, suscita in noi un dovere morale, un'interrogazione ininterrotta che non può mai accontentarsi di un sapere particolare" [Sini 20।8].

In fact, there are many disciplines that contribute to the preservation not only of the material itself, but also of the memory of how an architectural asset has changed and has been perceived over time. From photography to relief and its graphic restitution, to the construction of three-dimensional models, each with its own potential and limits.

In this text it was proposed the restitution of the survey, conducted largely through the total station, integrating where possible with direct survey, as one of the possible ways for the creation of a memory, albeit partial, which in fact relied not only on photography but also on the study of historical drawings, giving a possible current perspective by merging the here and now of the survey and the historical traces found in the research. For this reason, even the relief and the graphic restitution can contribute to the construction of the memory of an architectural object and in a certain sense prevent it, being forgotten, from disappearing definitively. Furthermore, through the study of historical documentation it is possible to trace its change over time and sometimes also the reason for these changes. While with the relief and representation it provides a vision of its current state, because as Purini states: "Rappresentare è pensare e costruire simulacri. Simulacri di ciò che esiste, di ciò che è esistito e che non esiste più, di ciò che non è più come fu all'inizio della sua esistenza o in qualche altra sua fase e che vuole essere restituito alla sua immagine primaria" [Purini 1999, p. I0].

In conclusion, we want to highlight a non-secondary aspect that has not been discussed, but that is very dear to the writer and the inhabitants of Augusta is that the stretch of sea on which Avalos strongly insists is full of negative meanings, there in fact, it overlooks the industrial area between Augusta and Syracuse that has brought so many evils to the environment and to the population, but despite this it, metaphorically, takes on both the characteristics of the sources of the oracle of Trofonius. On the one hand, as Lete isolated it from the mainland, making it difficult to access and, with some exceptions, it almost made it forget its existence, on the other hand, however, as Mnemosyne, it preserved it from excessive tampering, locking it in an almost timeless dimension.

\section{Notes}

[I] Based on the degree thesis in Architecture by Eleonora Di Mauro, Avalos Fort: a stone wreck, relief, indications for restoration and reuse. A.A. 2018/2019, University of Catania. Tutor prof. Eugenio Magnano di San Lio, cotutor prof. Maria Rosaria Vitale.

[2] As Nucifora says, an antinomy has always existed between the watchtowers and the lighthouses, in reference to their function and the direction in which the information from or to the sea was, through them, conveyed.

\section{References}

Anonimo (1770). Raccolta di tutti i più rinomati scrittori dell'Istoria generale del Regno di Napoli. Tomo X. Napoli: Stamperia di Giovanni Gravier. 1770.

Don Boccone Paulo, Don Boccone Silvio ( 1697 ). Museo di Fisica e di esperienze Variato e decorato di osservazioni naturali e note Medicinali, e Ragionamenti secondo Prinicipii de' Moderni. Venezia. 1697.

Cacciaguerra Vincenzo (197I). La lanterna di torre Avalos. In Notiziario storico di Augusta, 6, dicembre 197I, pp. I 35 - I68.

Cardaci Alessio, Versaci Antonella (20 I 3). L'innovazione del rilievo fotografico per la conoscenza, la documentazione e fruizione dei beni culturali. In DisegnareCon, 12, 2013, 6, pp. I- 10.

Conti Flavio (20।8). Prefazione. In Maglio Luigi, Taddei Domenico (a cura di). Le parole del castello, nomenclatura castellana. Napoli: Giannini.

Dufour Liliane (1992). Atlante storico della Sicilia, le città costiere nella cartografia manoscritta 1500-1823. Palermo: Arnaldo Lombardi. pp. $14-17$. 
Dufour Liliane (1989). Augusta da città imperiale a città militare. Palermo: Sellerio.

Ferraguto Luciano (1862). Augusta di Sicilia al Parlamento italiano memoria dell'ingegnere civile dottor Luciano Ferraguto. Catania:Tipografia F.lli Pastore.

Maglio Luigi, Taddei Domenico (a cura di). (20।8). Le parole del castello, nomenclatura castellana. Napoli: Giannini.

Magnano di San Lio Eugenio (2016). The "spanish school" bastion defence. In Giorgio Verdiani (ed.). Defensive architecture of the Mediterranean XV to XVIII century. Firenze: Didapress. vol 3, pp. I I9- 126.

Mazzarella Salvatore, Zanca Renato (1985). Il libro delle torri. Le torri costiere di Sicilia nei secoli XVI-XX. Palermo: Sellerio. pp. $103,104$.

Nucifora Sebastiano (2005). Sul limitare. In Bartolomei Cristiana, Amoruso Giuseppe (a cura di). L'architettura dei fari italiani. Firenze: Alinea, 2005, volume IV, pp. 256.

Purini Franco (1999). Costruire lo sguardo. In XY, 35-36-37, 1999, pp. I0- I I.

Santoro Rodo ( 1985). La Sicilia dei castelli: la difesa dell'isola dal VI al XVIII secolo, storia e architettura. Edizioni Pegaso s.r.l.

Sini Carlo (2018). La verità? Sta sempre nella relazione. In Avvenire.it, 29 marzo 20 I 8. <https://www.avvenire.it/agora/pagine/ carlo-sini-filosofo-intervista>.

Trigilia Lucia, Agnello Giuseppe (1994). La spada e l'altare: architettura militare e religiosa ad Augusta dall'età sveva al Barocco. Palermo: Arnaldo Lombardi.

Villabianca Francesco Maria Emanuele e Gaetani (marchese di), (1986). Torri di guardia dei litorali della Sicilia (a cura di Salvo Di Matteo). Palermo: Edizioni Giada.

Vita Francesco (1996). Inesto istorico della città di Augusta 1653 (a cura di Dufuor Liliane). Siracusa: Arnaldo Lombardi Promozione.

Author

Eleonora Di Mauro, Università degli Studi di Palermo, eleonora.dimauro@unict.it

To cite this chapter. Di Mauro Eleonora (2020). Forte Avalos: tra memoria e oblio, un disegno per ricordare/Fort Avalos: memory and oblivion, a drawing to remember. In Arena A., Arena M., Brandolino R.G., Colistra D., Ginex G., Mediati D., Nucifora S., Raffa P. (a cura di). Connettere. Un disegno per annodare e tessere. Atti del $42^{\circ}$ Convegno Internazionale dei Docenti delle Discipline della Rappresentazione/Connecting. Drawing for weaving relationships. Proceedings of the 42th International Conference of Representation Disciplines Teachers. Milano: FrancoAngeli, pp. 2098-2 1 1 7. 